\title{
The impact of urban light rail transit on double-story terraced property values in the Greater Kuala Lumpur, Malaysia
}

\author{
Mohd Faris Dziauddin \\ Department of Geography, Faculty of Human Sciences, Universiti Pendidikan Sultan Idris, Malaysia
}

Received: 2019-07-07 Accepted: 2021-03-10

Keywords:

Urban area;

urban light rail transit;

residential property values;

hedonic pricing model;

Greater Kuala Lumpur.

Correspondent email:

faris@fsk.upsi.edu.my

\begin{abstract}
It is generally believed that a rail transit system plays a pivotal role in increasing land values, and subsequently, residential property values. Despite this general belief, there is considerably little empirical research on the impact of urban light rail transit systems on residential property values in developing countries setting. This study, therefore, investigates the impact of proximity to urban light rail transit on double-story terraced property values in the Greater Kuala Lumpur, Malaysia, using hedonic pricing model. The findings suggest there is a statistically positive and significant impact of urban rail transit on surrounding double-story terraced residential property values - estimated at a premium of $12.3 \%$ and $9.8 \%$ for properties located up to $1000 \mathrm{~m}$ and $1001-2000 \mathrm{~m}$ to the nearest light rail transit station respectively. The findings of the study are useful for investors and developers, namely to build more houses near urban rail transit infrastructure since they lead to significant appreciation in value.
\end{abstract}

\section{Introduction}

Introducing urban light rail transit is expected to increase residential property values that are located within a short distance to the nearest station. This is due to the fact that residential properties that are located within a short distance to the nearest station enjoy easy access to work and amenities, greater mobility options and reduced transportation costs (Forouhar, 2016). Hence, in most cases, greater access to the nearest urban light rail transit stations is valued positively by property buyers and as a result, residential property values are significantly higher. Over the past 50 years or so, there have been numerous studies conducted to establish a positive relationship between urban light rail transit and residential property values. But, a limited of them have been conducted in the developing countries. Hence, the main objective of this study is to investigate the impact of proximity to urban light rail transit on doublestory terraced property values in Greater Kuala Lumpur, Malaysia, using hedonic pricing model. Since the common way to finance public transport infrastructure is from the government (federal or local governments), either through tax revenues or borrowing, established the positive relationship between urban light rail transit and residential property values should certainly be considered as a mechanism to influence the public decision and rationalize public investment in public transport infrastructure.

From a theoretical point of view, the bid-rent theory established by Alonso (1964) and Muth (1969) provides better equipment to understand the relationship between urban light rail transit and residential property values. The bid-rent theory suggests that improvement in the transport system that increases accessibility to work, shopping and recreational sites which reduces transport costs is reflected in higher land value along the corridor rather (particularly around stations) than land outside the corridor. As a result, we should expect a higher bid-rent surface at transit stations.

One of the earliest studies to establish the positive relationship between urban rail transit and residential property values was carried in Philadelphia, New Jersey by Boyce, Allen, Mudge, Slater, \& Isserman (1972). The results indicate that statistically significant positive impact of urban rail transit on property values in which for every minute of savings to the city centre, the residential property values increased by USD $\$ 149$ to $\$ 200$. Since then, a numerous studies have been carried out in many cities to establish a positive relationship between urban rail transit and residential property values: Amsterdam, Rotterdam, and Enschede (Debrezion, Pels, \& Rietveld, 2011), Beijing (Feng, $\mathrm{Li}$, and Zhao, 2011; Gu \& Guo, 2008), Charlotte (Yan, Delmelle, \& Duncan, 2012), Dublin (Mayor, Lyons, Duffy, \& Tol, 2012), Ottawa (Hewitt \& Hewitt, 2012), Houston (Pan, 2019), Montreal (Dubé, Thériault, \& Des Rosiers, 2013), Phoenix (Golub, Guhathakurta, \& Sollapuram, 2012), Greater Kuala Lumpur (Dziauddin, Alvanides, \& Powe, 2013), Minnesota (Cao \& Lou, 2017), Tehran (Forouhar, 2016), and Warsaw (Trojanek \& Gluszak, 2017).

In the North America, Yan et al. (2012) discover residential properties located within 402 metres and 1,609 metres from Charlotte's light rail transit stations increased in value. In Ottawa, Hewitt and Hewitt (2012) report the OTrain stations has a statistically significant impact on the 
residential property values. A study conducted by Dubé et al. (2013) suggest proximity to urban rail transit stations increased residential property values by $11 \%$. Golub et al. (2012) find that residential property values decreases with distance at different time periods namely the announcement, construction and operation. Cao and Lou (2017) show residential property values increases by US $\$ 9.2 / \mathrm{sq}$. $\mathrm{ft}$. after an announcement of the construction of LRT and by US\$13.7/ sq. $\mathrm{ft}$. after the opening.

In the European context, Debrezion et al. (2011) show in Amsterdam, Rotterdam, and Enschede, residential property values are influenced by the most higher passenger volumes station than proximity to the nearest rail transit station. Mayor et al. (2012) investigate the impact of Dublin Area Rapid Transit (DART) and Luas (light rail transit) on residential property values. Findings show that residential property values appreciate by $5 \%$ and $7-8 \%$ with proximity to DART and Luas, respectively. Trojanek and Gluszak (2017) estimate benefits of residential property values located near subways in Warsaw. They conclude for per $\mathrm{km}$ increase to the subway station reduces residential property values by approximately $2.5 \%$ in 2008 to $3.0 \%$ in 2015 .

In Asian cities, Feng, Li, and Zhao (2011) find that residential property values located within 2 kilometres from the Subway Line Five in Beijing, China are significantly increased. A recent study by Dziauddin et al. (2013) also report a significant increase in values of residential property which is closer to urban rail transit stations in the Greater Kuala Lumpur.

Whilst most studies found significant positive relationships, yet each study reveals varying positive results. The conclusion of results in the review has been difficult. Therefore, why residential property values react differently to the presence of urban rail transit requires further investigation.

\section{Method}

As mentioned previously, this study employs hedonic pricing model to investigate the impacts of urban light rail transit on double-story terraced residential property values. Hedonic pricing model is based on Lancaster's (1966) model of consumer demand which recognises the utility of goods is determined by their attributes. In the case of residential property for example, the willingness to pay of an individual for a given property depends on the utility of its various characteristics. This technique, however, became well known after Rosen in 1974 called it hedonic pricing, arguing goods can be valued based on their various characteristics. Therefore, total value of a good can be considered as a sum of each homogenous characteristics, and in an equilibrium market each characteristic has a unique implicit price. A common form of ordinary least square (OLS) regression model can be expressed as follows:

$$
Y_{\mathrm{i}}=\beta_{0}+\sum \beta_{\mathrm{i}} X_{\mathrm{i}}+\varepsilon_{\mathrm{i}}
$$

where the dependent variable $Y_{\mathrm{i}}$ is property price for observation $i$; $X_{\mathrm{i}}$ represents the value of factor for observation $i ; \beta_{0}$ is the constant; $\beta_{\mathrm{i}}$ is the regression coefficient and $\varepsilon$ is an error term.

\section{Data Acquisition}

Data for double-story terraced properties to build the hedonic pricing model (i.e. sales values and structural attributes) were collected from the Department of Valuation and Services, Malaysia (Kuala Lumpur, Shah Alam and Gombak branch). A total of 1,640 double-story terraced properties are examined for the period of 2009 and 2010, 12 years after the light rail transit in Greater Kuala Lumpur began its service. Note that the period of 2009 and 2010 are chosen due to data availability as well as stability in housing markets. In addition, this study uses cross-sectional of data located within a catchment area of three-kilometer radius (straight-line-distance) of light rail transit stations. Planners typically assume people would be willing to walk up to 1,200 meters to reach rail transit stations (see O'Sullivan \& Morrall, 1996). In this study, the distance studied is a three-kilometer radius of the light rail transit stations. The impact of light rail transit services could reach up to a maximum distance of three kilometers since this catchment area is served by feeder bus services to transport passengers to and from the nearest light rail transit station. In addition, this study intends to capture the variation in property value not necessarily observed within a 1,200-meter radius. Based on the analysis, it is found that the average distance between observations to a station is about 1,700 meters.

Whilst, data on the base map, land parcel, and land use were obtained from the Department of Survey and Mapping Malaysia. They are highly reliable as the Department is known as a professional body that provides data in Malaysia include not only topographic map but also cadastral and land use maps. In order to measure the proximity of each residential property to the nearest locational attributes using the shortest possible straight-line distance (measures perceived distance), geographic information systems (GIS) is employed to position each residential property accurately on a local map using geographical coordinates (latitude and longitude) identified from Google Maps. The identification of geographical coordinates from Google Maps is guided by house addresses for each residential property collected from the Department of Valuation and Services Malaysia data set. Note that the near distance function available in the ArcGIS software package is used to measure the shortest possible straight-line distance.

\section{Data Processing}

To eliminate outliers from the data set, filters include sales values of residential property, floor size and number of bedrooms are applied. The common rule of thumb used to detect for outliers is beyond three standard deviations from the mean. The result of this process is the sales price of residential property less than MYR 100,000 (USD 31,153) is eliminated because they are not arms-length sales values in the Greater Kuala Lumpur housing market. The number of bedrooms less than two and floor area of less than 46 square meters are eliminated because these values are not representative of landed properties in the Greater Kuala Lumpur. Finally, only 1,419 units of double-story terraced residential property sales data are used for final analysis. The structural characteristics for the residential properties used for final analysis include floor size (FLOORSIZE), lot size (LOTSIZE), number of bedrooms (BEDS) and ownership rights (FREEHOLD) were obtained from the data provider. However, several important structural characteristics that are not available from the data set include property age and the number of bathrooms. 
Two dichotomous urban rail transit variables are included in the final regression model and are the focus of this study: (1) residential properties located up to $1000 \mathrm{~m}$ to the nearest LRT station (DISTLRT1), and (2) residential properties located within $1001-2000 \mathrm{~m}$ to the nearest LRT station (DISTLRT2). Other locational characteristics include proximity to city centre (CBD), hospital (HOSP), recreational park $(P A R K)$, primary school (PRIMARYSCH), high-performing secondary school (HP_SECONDARYSCH), forest (FOREST), industrial area (INDUSTRIAL), the Central Side (CENTRAL) and the South Side (SOUTH) of Kuala Lumpur.

Table 1 shows the summary statistics of dependent and exploratory variables used to estimate the impact of urban light rail transit on residential property values in this study. Based on a sample of about 1,640 , following observation can be made: (1) property sales values range from MYR 100,000 (USD 31,152, with the FOREX rate at MYR 3.21 or USD 1.00 in 2010) to nearly MYR 3 million (USD 934,579); (2) the average property sales value is MYR 463,907 (USD 144,519); (3) the average property has a floor size of around 139 square metre or 1,500 square feet; and (4) there are units with as low as 55 square metre or 592 square feet to as large as 372 square metre or 4,000 square feet.

In regression analysis, it is common to expect the presence of multicollinearity between the exploratory variables. Since the exploratory variables may be highly correlated, Pearson's correlation coefficient and variance inflation factors (VIFs) of each exploratory variable are employed in this study. According to Orford (1999) and Neter et al. (1985), a Pearson's correlation coefficient value of 0.8 and above and a variance inflation factor value of 10 and above is generally considered harmful collinearity. In this study, pairs of exploratory variables that produce a correlation coefficient value of 0.8 or higher and variance inflation factor value of 10 or higher are removed from the final model. Another major concern with regression analysis is the existence of heteroscedasticity. The existence of heteroscedasticity in the final data set is tested by using the Park test and its results suggest there is no heteroscedasticity in the error variance.

To capture the impact of urban rail transit on doublestory terraced residential property values, several different functional forms were explored. The final form of hedonic pricing model equation takes the following form:

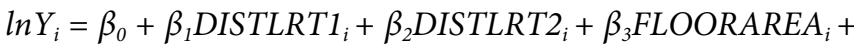
$\beta_{4}$ LOTRAREA $_{i}+\beta_{5}$ BEDROOMS $_{i}+\beta_{6}$ FREEHOLD $_{i}+$ $\beta_{7}$ SHOPCENTRE $_{i}+\beta_{8}$ HOSPITAL $_{i}+\beta_{9}$ PARKi + $\beta_{10}$ PRIMARYSCH $_{i}+\beta_{11}$ HP_SECONDARYSCH $H_{i}+$ $\beta_{12}$ FOREST $_{i}+\beta_{13}$ CBD $_{i}+\beta_{14}$ INDUSTRIAL $_{i}+\beta_{15}$ CENTRAL $_{i}+$ $\beta_{16} \mathrm{SOUTH}_{i}+\varepsilon_{i}$

where $\ln Y_{i}$ is natural logarithm of the sale price of a property in Ringgit; DISTLRT1 is a dichotomous variable for residential properties located within $1000 \mathrm{~m}$ to the nearest LRT station; DISTLRT2 is a dichotomous variable for residential properties located within 1001 - $2000 \mathrm{~m}$ to the nearest LRT station; FLOORAREA is the floor area of property in square feet; LOTAREA is the land area of property in square feet; BEDROOMS is a dichotomous variable for property with four or more bedrooms; FREEHOLD is a dichotomous variable for property with freehold holding status. SHOPCENTRE, HOSPITAL, PARK, PRIMARYSCH, HP_SECONDARYSCH, CBD, FOREST and INDUSTRIAL are respective proximity to the nearest shopping centre, hospital, recreational park, primary school, high performance secondary school, central business district, forest and industrial area which are all measured in metre. Finally, CENTRAL and SOUTH are dichotomous variables associated with the properties located in the central and southern sides of Greater Kuala Lumpur, respectively. $\beta$ are parameters to be estimated, and $\varepsilon$ is the normally distributed error term. In the semi-log functional form, the interpretation of the estimated coefficients $\beta$ associates to their proportional (multiplied by 100).

Table 1. Descriptive statistics of dependent and independent variables

\begin{tabular}{|c|c|c|c|}
\hline & Units & Mean & S.D. \\
\hline PRICE & MYR & $463,906.61$ & $280,676.81$ \\
\hline Ln Price (dependent variable) & MYR & 12.91 & 0.52 \\
\hline DISTLRT1 & Dichotomous variable ( 0 or 1$)$ & 0.20 & 0.40 \\
\hline DISTLRT2 & Dichotomous variable ( 0 or 1$)$ & 0.38 & 0.49 \\
\hline FLOOSIZE & Square feet & $1,549.74$ & 407.69 \\
\hline LOTSIZE & Square feet & $1,692.62$ & 755.76 \\
\hline$B E D S$ & Dichotomous variable ( 0 or 1 ) & 0.39 & 0.49 \\
\hline FREEHOLD & Dichotomous variable ( 0 or 1 ) & 0.67 & 0.47 \\
\hline SHOPCENTRE & Metre & $1,596.29$ & $1,003.98$ \\
\hline HOSP & Metre & $4,411.42$ & $1,927.68$ \\
\hline PARK & Metre & $2,532.41$ & $1,230.34$ \\
\hline PRIMARYSCH & Metre & $1,049.57$ & $1,053.64$ \\
\hline HP_SECONDARYSCH & Metre & $3,876.53$ & $2,050.43$ \\
\hline$C B D$ & Metre & $8,509.49$ & $2,633.02$ \\
\hline FOREST & Metre & $1,919.91$ & $1,144.00$ \\
\hline INDUSTRIAL & Metre & $3,749.00$ & $2,272.79$ \\
\hline CENTRAL & Dichotomous variable ( 0 or 1$)$ & 0.30 & 0.46 \\
\hline SOUTH & Dichotomous variable ( 0 or 1$)$ & 0.21 & 0.41 \\
\hline
\end{tabular}




\section{Results and Discussion}

The results of the estimation of Equation (2) are presented in Table 2. The model fits the cross-sectional data well and explains $62 \%$ of the variation in double-story terraced residential property values. All independent variables that influence double-story terraced residential property values are significant at the 0.05 level and have the expected positive or negative signs. The estimated coefficients reveal that light rail transit has a positive and significant impact on surrounding double-story terraced residential property values - estimated at a premium of $12.3 \%$ and $9.8 \%$ for properties located up to $1000 \mathrm{~m}$ (DISTLRT1), and 1001 $2000 \mathrm{~m}$ (DISTLRT2) to the nearest light rail transit station respectively. The results support the Alonso-Muth-Millsbased hypothesis that residential properties around urban rail transit stations capitalise in value due to potential savings in transports costs. The impact of other structural and locational attributes variables is also estimated. The results show for every square foot increase in the floor size (FLOORSIZE) and lot size (LOTAREA), the double-story terraced residential property values are estimated at a premium of $0.04 \%$ and $0.02 \%$ respectively. As expected, the effect of number of bedrooms (BEDROOMS) on residential property values is also positive - double-story terraced residential property units with four or more bedrooms are to sell at a premium of $4.2 \%$. Residential property units with a freehold ownership rights (FREEHOLD) sell at a premium of $18.8 \%$.

In terms of locational attribute variables, the estimated coefficients suggest that double-story terraced residential property values increase if properties are located in close proximity to the nearest shopping centre (SHOPCENTRE), proximity to the nearest recreational park $(P A R K)$, proximity to the nearest high-performance secondary school (HP_SECONDARYSCH), and proximity to the nearest forest (FOREST) - estimated at a premium of $0.008 \%, 0.003 \%$, $0.007 \%$ and $0.003 \%$ for every metre closer to these locational attributes respectively. The estimated coefficient further denotes the proximity to the city centre $(C B D)$ negatively impacts residential property values - residential property units decrease in value by about $0.002 \%$ for every metre away from the city centre, which confirms the monocentric urban structure theory for Greater Kuala Lumpur. Results from estimation also suggest residential property units located at the Central Side (CENTRAL) and the South Side (SOUTH) of Kuala Lumpur which have the largest share of middleincome, upper middle-income and upper-income households, command a premium of $30.3 \%$ and $20.1 \%$ respectively over similar double-story terraced residential properties located in other parts of the Greater Kuala Lumpur.

The results also indicate that, for every metre closer to the nearest hospital (HOSPITAL), primary school (PRIMARYSCH), and industrial area (INDUSTRIAL), the double-story terraced residential property values are sell at discount of $0.01 \%, 0.007 \%$, and $0.003 \%$ respectively.

Overall, this study contributes to the growing literature on the impact of urban light rail transit on residential property values in three ways, (1) it investigates the impact of urban light rail transit on double-story terraced residential property values in the developing country, i.e., Malaysia; (2) the impact of the Greater Kuala Lumpur's urban light rail is investigated by utilising the 2009 and 2010 residential property database, which allows the effects to be captured after a reasonable time span, i.e., 12 years after the opening of the first urban light rail transit in the country; and (3) the impact of the Greater Kuala Lumpur's urban light rail is measured by employing two distance intervals namely up to $1000 \mathrm{~m}$ and $1001-2000 \mathrm{~m}$ of the nearest LRT station.

Regarding (2), Gu and Guo (2008) found that the impact of Beijing subway line 13 on suburban residential property values two years after the opening was no longer significant. Another study by $\mathrm{He}$ and Jing (2013) on Beijing subway line 4 found that the impact lasted for four years. In addition, Dziauddin et al. (2013) study the Kelana Jaya LRT line in the Klang Valley, Malaysia based on the data in 2004 which is six years after the opening suggested that the impact was marginal. The finding of present study, however, suggest that double-story terraced residential property values appreciated largely 12 years after the opening. This finding reflects the longer time that property buyers place to the availability of urban light rail transit in the area. In car loving country such as Malaysia it is not surprised to expect property buyers take longer time to respond positively towards the existence of urban light rail transit especially when Malaysian have witnessed the hikes in fuel and parking rates (particularly in the Kuala Lumpur city centre). As a study conducted by Chiu Chuen, Karim, and Yusoff (2014) in Greater Kuala Lumpur denotes that factors such as parking costs, fuel prices and car prices may considerably influence the likelihood of commuters using a car as their main mode of transport.

Regarding (3), the largest positive impact tends to occur within $1000 \mathrm{~m}$ of the nearest LRT station. This finding is consistent with previous studies (Dubé et al., 2013; Dziauddin et al., 2013; Feng et al., 2011) suggesting that residential property values that are close to stations are higher than those located further away. For example, studies carried out by Dubé et al. (2013) in Montreal, Canada, and Feng et al. (2011) in Beijing, China found that the positive impact of rail transit on residential property values diminished with an increase of distance from the station.

\section{Conclusion}

This study uses a hedonic pricing model to investigate the impact of proximity to light rail transit on residential property values based on a sample of double-story terraced properties in the Greater Kuala Lumpur, Malaysia. The results show that light rail transit has a significant positive impact on proximate double-story terraced property values up to a $1000 \mathrm{~m}$ and $1001-2000 \mathrm{~m}$ radius to the nearest light rail transit station. The fit of the equation is found to be satisfactory as an adjusted $R^{2}$ higher than $60 \%$ for crosssectional data. The impact is the highest when double-story terraced properties are located up to a $1000 \mathrm{~m}$ radius to the nearest light rail station. It can be concluded that urban light rail transit plays a significant role in determining residential property values. The results of this study can provide some new insights for investors and developers to fully consider of building more houses near urban rail transit infrastructure since there is a significant value appreciation. The results of this study may also help home buyers select reasonably locations when buying a new house so that it will ensure the investment appreciates in value over time.

While the results are robust in investigating the impact of urban light rail transit on residential property values, a limitation of this study lies it its modelling approach and temporal effects. The main disadvantage of OLS is that it has 
Table 2. Results of the hedonic pricing model $(n=1,419)$

\begin{tabular}{|c|c|c|c|c|}
\hline \multicolumn{5}{|c|}{ Ordinary least square } \\
\hline & Coefficient $(\beta)$ & t-ratio & Sig. & VIF \\
\hline Intercept & 11.588448 & 166.9 & 0.00 & \\
\hline DISTLRT1 & 0.122668 & 4.6 & 0.00 & 1.6 \\
\hline DISTLRT2 & 0.098065 & 4.6 & 0.00 & 1.5 \\
\hline FLOORAREA & 0.000436 & 15.8 & 0.00 & 1.7 \\
\hline LOTAREA & 0.000214 & 16.5 & 0.00 & 1.3 \\
\hline BEDROOMS & 0.041764 & 2.3 & 0.02 & 1.1 \\
\hline FREEHOLD & 0.188286 & 8.8 & 0.00 & 1.4 \\
\hline SHOPCENTRE & -0.000077 & -5.4 & 0.00 & 2.8 \\
\hline HOSPITAL & 0.000100 & 10.3 & 0.00 & 4.9 \\
\hline$P A R K$ & -0.000025 & -2.3 & 0.02 & 2.4 \\
\hline PRIMARYSCH & 0.000066 & 3.9 & 0.00 & 4.3 \\
\hline HP_SECONDARYSCH & -0.000065 & -7.4 & 0.00 & 4.4 \\
\hline$C B D$ & -0.000023 & -3.5 & 0.00 & 4.1 \\
\hline FOREST & -0.000032 & -3.0 & 0.00 & 2.1 \\
\hline INDUSTRIAL & 0.000033 & 6.0 & 0.00 & 2.1 \\
\hline CENTRAL & 0.303299 & 11.4 & 0.00 & 2.0 \\
\hline SOUTH & 0.201159 & 6.5 & 0.00 & 2.2 \\
\hline
\end{tabular}

not controlled spatial autocorrelation and heterogeneity so that it assumed the relationship being investigated to be homogenous over a geographical area. Regarding temporal effects, though the two sets of data in 2009 and 2010 used in this study, they are not enough to plot out the changes of effects at a yearly base. Based on these two limitations, future study should consider spatial econometrics modeling and the temporal difference in investigating the impact of urban light rail transit on residential property values.

\section{Acknowledgment}

The author would like to thank the Ministry of Higher Education, Malaysia through Fundamental Research Grant number 2016-0070-106-02 for funding this research. Also, the author would like to thank the reviewers for their constructive comments.

\section{References}

Alonso, W. (1964). Location and land use: Towards a general theory of land rent. Cambridge, MA: Harvard University Press.

Boyce, D. E., Allen, B., Mudge, R. R., Slater, P. B., \& Isserman, A. M. (1972). Impact of Rapid Transit on Suburban Residential Property Values and Land Development: Analysis of the Philadelphia Lindenwold High-speed Line. Final Report. Philadelphia: University of Pennsylvania, Department of Regional Science.

Cao, X., \& Lou, S. (2017). When and how much did the Green Line LRT increase single-family housing values in St. Paul, Minnesota? Journal of Planning Education and Research. DOI.org/10.1177/0739456X17707811.

Chiu Chuen, O., Karim, M. R., \& Yusoff, S. (2014). Mode choice between private and public transport in Klang Valley, Malaysia. The Scientific World Journal. https:// doi.org/10.1155/2014/394587

Debrezion, G., Pels, E., \& Rietveld, P. (2011). The impact of rail transport on real estate prices: an empirical analysis of the Dutch housing market. Discussion Paper No. 06-031/3, Tinbergen Institute, Rotterdam.
Dubé, J., Des Rosiers, F., Thériault, M., \& Dib, P. (2011). Economic impact of a supply change in mass transit in urban areas: a Canadian example. Transportation Research Part A: Policy and Practice, 45 (1), 46-62.

Dziauddin, M. F., Alvanides, S. \& Powe, N. (2013). Estimating the effects of light rail transit (LRT) system on residential property values: A hedonic house price approach. Jurnal Teknologi, 61 (1), 35-47.

Feng, C., Li, W., \& Zhao, F. (2011). Influence of rail transit on nearby commodity housing prices: A case study of Beijing subway line five. Acta Geographica Sinica, 66 (8), 1055-1062.

Forouhar, A. (2016). Estimating the impact of metro rail stations on residential property values: evidence from Tehran, Public Transport, 8 (3), 427-451.

Golub, A., Guhathakurta, S., \& Sollapuram, B. (2012). Spatial and temporal capitalization effects of light rail in Phoenix: from conception, planning, and construction to operation. Journal of Planning Education and Research, 32 (4), 415-429.

Gu, Y., \& Guo, R. (2008). The impacts of the rail transit on property values: Empirical study in Batong line of Beijing. Economic Geography, 48 (3), 411-414.

Hewitt, C. M., \& Hewitt, W. E. (2012). The effect of proximity to urban rail on housing prices in Ottawa. Journal of Public Transportation, 15 (4), 43 - 65.

Lancaster, K. (1966). A new approach to consumer theory. Journal of Political Economy, 74, 132-157.

Mayor, K., Lyons, S., Duffy, D., \& Tol, R. S. J. (2012). A hedonic analysis of the value of rail transport in Greater Dublin Area. Journal of Transport Economics and Policy, 46 (2), 239-261.

Muth, R. (1969). Cities and Housing: The Spatial Pattern of Urban Residential Land Use. Chicago: Chicago University Press.

Neter, J., Wasserman, W., \& Kutner, M. H. (1985). Applied linear statistical models. Irwin, Homewood.

O'Sullivan, S., \& Morrall, J. (1996). Walking distance to and from light rail transit stations. Transportation Research Record, $1538,19-26$.

Pan, H., \& Zhang, M. (2008). Rail transit impacts on land use: Evidence from Shanghai, China. Transportation Research Record, 2048, 16-25.

Rosen, S. (1974). Hedonic prices and implicit markets: product 
differentiation in pure competitions. Journal of Political Economy, 72, 34-55.

Trojanek, R., \& Gluszak, M. (2018). Spatial and time effect of subway on property prices. Journal of Housing and the Built Environment, 33, 359-384.

Yan, S., Delmelle, E., \& Duncan, M. (2012). The impact of a new light rail system on single-family property values in Charlotte, North Carolina. Journal of Transport and Land Use, 5 (2), 60 67. 